AperTO - Archivio Istituzionale Open Access dell'Università di Torino

\title{
Multiple sources for the German scandal construction
}

\section{This is the author's manuscript}

Original Citation:

Availability:

This version is available http://hdl.handle.net/2318/139458

since 2016-09-12T17:02:53Z

Terms of use:

Open Access

Anyone can freely access the full text of works made available as "Open Access". Works made available under a Creative Commons license can be used according to the terms and conditions of said license. Use of all other works requires consent of the right holder (author or publisher) if not exempted from copyright protection by the applicable law. 
This is the author's final version of the contribution published as:

L. GAETA. Multiple sources for the German scandal construction. STUDIES IN LANGUAGE. 37 (3) pp: 566-598.

When citing, please refer to the published version.

Link to this full text:

http://hdl.handle.net/2318/139458 


\title{
Multiple sources \\ for the German scandal construction*
}

\author{
Livio Gaeta \\ University of Turin
}

\begin{abstract}
The interaction of several cases of grammaticalization going back to different source constructions may have dramatic consequences on a linguistic system. This paper discusses the so-called German scandal construction, which consists of a verbal complex displaying a number of synchronic form-meaning mismatches. The scandal is solved if a diachronic point of view is adopted, which shows that the mismatches result from the intraference of two different source constructions expanded in the course of the German linguistic history, namely the Perfekt construction and the $z u$-infinitive construction.
\end{abstract}

Keywords: infinitive, perfect, form/function mismatch, auxiliary, German

\section{Introduction}

Recently, the word scandal has been used in connection with the following German construction (cf. Vogel 2009): ${ }^{1}$

(1) Hans bedauert, es nicht verhindert haben $_{1}$ zu können ${ }_{2}$. Hans regrets it not prevent:PSTPTCP have:INF to can:INF 'Karl regrets not having been able to prevent it'.

The scandal refers to the fact that no single piece of the nonfinite verbal complex contained in the sentence is logically justified. First, the use of the past participle verhindert instead of the infinitive verhindern is unexpected. Second, the infinitive haben appears in an unexpected place with regard to the normal German verb-final linearization, which also occurs as a possible, even though less frequent variant:

(2) Hans bedauert, es nicht verhindern gekonnt $_{2} \quad$ zu haben ${ }_{1}$. Hans regrets it not prevent:INF can:PSTPTCP to have:INF 'Karl regrets to have not been able to prevent it'. 
Notice furthermore that the unexpected linearization in (1) has the effect of separating the preposition $z u$, which is normally required with subordinate infinitives in German similar to its English cognate to, from its logical dependency, namely haben. In other words, the preposition $z u$ keeps its expected position in spite of the migration of the infinitive which it is logically connected with.

Finally, besides being displaced, the use of the infinitive können in (1) instead of a past participle is also logically unexpected, which is attested in the less frequent variant in (2).

In sum, the scandal consists in a double type of mismatches within the verbal complex, which give rise to two further subtypes:

- deviant form/meaning relation:

- a past participle (verhindert) instead of an infinitive (verhindern)

- an infinitive (können) instead of a past participle (gekonnt)

- deviant linearization:

- $\quad$ inverted order of haben ${ }_{1} z u$ können ${\text { instead of }{ }^{*} \text { können }_{2} z u \text { haben }}_{1}$

- displacement of $z u$ with regard to its logical dependency haben

As emphasized by Francis \& Michaelis (2003:2), a mismatch should be understood as a synchronic form-meaning discrepancy in which form-function mappings are "incongruent with respect to more general patterns of correspondence in the language". Two main types of mismatch have been distinguished by Francis \& Michaelis (2003): complexity and content mismatches. In a complexity mismatch, a discrepancy occurs in the number of elements involved (and, consequently, in the complexity of the structure) at different levels of representation. This is exemplified by the occurrence of expletives as in the English sentence It rains, in which no semantic content can be attributed to the subject pronoun. A content mismatch, on the other hand, is characterized by incongruous mapping in the content of items from two different levels of representation as in both types of mismatches occurring in the scandal construction. ${ }^{2}$

The authors' emphasis on synchrony aims at exploring "the implications of mismatch phenomena in general for grammatical theory", in that " $[\mathrm{m}]$ ismatch phenomena challenge our conceptions of grammar and are thereby of vital importance for the development of grammatical architectures" (Francis \& Michaelis 2003:5).

On the other hand, mismatches are also highly relevant from a diachronic perspective, in particular when grammaticalization is involved (cf. Gaeta 2008). In this light, mismatches arise as a consequence of the expansive potential of grammaticalization, which begins at a certain time in a given context with a specific construction and is expanded, affecting more and more (extensions of the initial) constructions. The synchronic mismatches may be due either to the simple arrest 
of the expansive potential or to the limits imposed on the expansion for some reason involving a superordinate level. At any rate, the effect is the same: it leaves part of the possible expansion domain unchanged or imperfectly changed. ${ }^{3}$

It must be stressed that there generally seems to be a ratio behind the arrest of the expansive force of a grammaticalization change, whether it be the (semantic) complexity of the unchanged domain or the possible conflicts opened by the new grammaticalized construction with other structural principles of a language. In keeping with this scenario, I will try, in what follows, to explain the scandal construction in German as the result of the expansion and the intertwining of two different source constructions, the Perfekt and the $z u$-infinitive constructions, which contribute with their own properties (and mismatches) to the synchronic complexity of the outcome.

In Section 2, the scandal construction is carefully analyzed, while in Section 3 accounts are discussed. Section 4 briefly introduces the diachronic perspective opened by the expansion of an innovation through a language grammar especially when multiple sources of grammaticalization are involved. The two diachronic sources of the scandal construction are discussed in Section 5, in which an explanation is suggested in terms of an intraference. Finally, Section 6 draws the conclusion.

\section{Properties of the scandal construction}

Let us review in more detail the scandalous properties of the nonfinite verbal complex contained in (1). First, it has to be observed that, besides the logical sequence in (2) above, the scandal construction is flanked by two other possible variants. The first one can be considered moderately scandalous because the lexical verb verhindern takes the expected infinitive form, while the other mismatches are present:

(3) Hans bedauert, es nicht verhindern haben $_{1}$ zu können . $_{2}$ Hans regrets it not prevent:INF have:INF to can:INF 'Karl regrets to have not been able to prevent it'.

Finally, the last possible variant is even recommended by the norm (cf. Bech 1963):

(4) Hans bedauert, es nicht haben ${ }_{1}$ verhindern ${ }_{3}$ zu können $_{2}$. Hans regrets it not have:INF prevent:INF to can:INF 'Karl regrets not having been able to prevent it'. 
Here, two properties are remarkable, which also occur in slightly different terms in all other variants except the logical one in (2). Namely, the content mismatch presented by the infinitive of the modal verb können instead of the expected past participle gekonnt and the deviant linearization in which the first piece of the verbal complex stands at the top and the rest follows in a right-to-left order: $\mathrm{V}_{1}$ $\mathrm{V}_{3} \mathrm{~V}_{2}$. The first phenomenon goes under the name of Infinitivus Pro Participio (= IPP, cf. Schmid 2005 for a recent survey) and - at least in the standard variety of German - also co-occurs with the second phenomenon, the peculiar linearization in (4). Both traits obligatorily characterize the finite version of the scandal construction:

(5) Maria bedauert, dass Karl es nicht hat ${ }_{1}$ verhindern ${ }_{3}$ können $_{2}$.

Maria regrets that Karl it not has prevent:INF can:INF

'Maria regrets that Karl could not prevent it'.

This correspondence is probably the reason why the variant in (4) is held to be norm-consistent, and should in fact be expected. It must be added that such an IPP construction is obligatory in German when the $V_{2}$ is a modal, and normal when the $\mathrm{V}_{2}$ is the verb lassen 'to let' employed with a causative value. Moreover, the perception verbs hören 'to hear' and sehen 'to see' also frequently display the IPP construction (6a), even though the logical construction corresponding to (2) is also frequently found (6b) in the latter case as well as in the case of lassen used with a permissive value:

(6) a. Maria bedauert, dass Karl mich allein hat ${ }_{1}$ ausgehen $_{3}$ sehen $_{2}$. Maria regrets that Karl me:ACC alone has go:out:INF see:INF 'Maria regrets that Karl saw me going out alone'.

b. Maria bedauert, dass Karl mich allein ausgehen gesehen $_{2}$ hat ${ }_{1}$. Maria regrets that Karl me:ACC alone go:out:INF seen has 'Maria regrets that Karl saw me going out alone'.

Notice that the expected type in (4) also presents the displacement of $z u$ with regard to its governing infinitive haben. Bech (1963) sees this displacement as a "violent solution" of the conflict between the rule requiring the linearization typical of the IPP as we have seen it in (5) and that requiring the logical sequence of (2), which more generally characterizes verbal complexes containing a $z u$-infinitive. We will come back to this question below.

In spite of the recommendations, the scandal construction is generally preferred over the expected variant, as shown by the results obtained by Vogel (2009) in his empirical investigation of the virtual corpus $\mathrm{W}$ from the COSMAS-IIRecherche-System of the Institut für deutsche Sprache (Mannheim) containing about 1.15 billion tokens: 
(7) a. ... verhindert haben $_{1}$ zu können ${ }_{2}$

b. ... verhindern haben $_{1}$ zu können 2

c. .... haben verhindern $_{3}$ zu können 2

d. ... verhindern gekonnt $_{2}$ zu haben ${ }_{1}$

Table 1

\begin{tabular}{|c|c|c|c|c|}
\hline & $\begin{array}{l}\text { (a) } \\
\mathrm{V}_{3} \text {-PART } \\
\text { haben }_{1} \\
z u \mathrm{~V}_{2} \text {-INF } \\
\end{array}$ & $\begin{array}{l}\text { (b) } \\
\mathrm{V}_{3} \text {-INF } \\
\text { haben } \\
z u \mathrm{~V}_{2} \text {-INF }\end{array}$ & $\begin{array}{l}\text { (c) } \\
\text { haben }_{1} \\
\mathrm{~V}_{3} \text {-INF } \\
z u \mathrm{~V}_{2} \text {-INF }\end{array}$ & $\begin{array}{l}(\mathrm{d}) \\
\mathrm{V}_{3} \text {-INF } \\
\mathrm{V}_{2} \text {-PART } \\
\text { zu haben }_{1}\end{array}$ \\
\hline $\mathrm{V}_{2}=$ causative lassen & 12 & 4 & 0 & 2 \\
\hline $\mathrm{V}_{2}=$ modal verbs & 62 & 0 & 1 & 6 \\
\hline $\mathrm{V}_{2}=$ permissive lassen & 3 & 2 & 0 & 19 \\
\hline $\mathrm{V}_{2}=$ perception verbs & 0 & 0 & 0 & 32 \\
\hline Total & 77 & 6 & 1 & 59 \\
\hline
\end{tabular}

As can be gathered from the table reported from Vogel (2009) to which the totals have been added, there is a great deal of synchronic variation involved here, which is not chaotic, however. The numbers are not impressive, but quite clear: the scandal construction (7a) and its logical counterpart (7d) are clearly preferred, while the other two types are recessive. In particular, the expected type $(7 \mathrm{c})$ is almost completely avoided.

Furthermore, there is a crucial factor influencing the choice of either of the most preferred types, namely the kind of $\mathrm{V}_{2}$ : if the latter consists of the causative lassen or of modal verbs, the scandal construction (7a) is preferred, whereas a $\mathrm{V}_{2}$ consisting of the permissive lassen or of a perception verb clearly triggers the preference of the logical type (7d). As pointed out above, exactly the same factor was said to be relevant for the finite variant of the scandal construction: the employment of the logical construction in the finite context is only possible when the $\mathrm{V}_{2}$ consists of perception verbs and the permissive lassen. This correspondence does not come as a surprise if considered from the perspective of the expansion of the Perfekt construction from the finite to the nonfinite context. We will come to this point below. In the next section, we will briefly discuss the accounts suggested in the literature in order to shed some light on the nature and the origin of this construction.

\section{Previous attempts to find an explanation}

The accounts available in the literature on the scandal construction can be grouped into three types: accounts which admit the pure irregularity of the phenomenon, 
accounts which recognize the failure of the extension of a rule, and accounts which rely on structural properties of the verbal system. Let us shortly review them before discussing the approach to be defended in this paper.

Against the conclusion that the scandal construction is highly irregular in the sense that it contains a number of mismatches, i.e. violations of regularities occurring in the language, little can be objected. However, the term irregular can be interpreted in at least two different ways. First, irregularity can be taken at a language-specific level, i.e. as a mismatch which does not deserve any further comment and must be accepted as such. This is more or less the conclusion reached by Sternefeld (2006: 660), who simply admits that a sentence like (1) contains "einige kuriose Diskrepanzen bezüglich morphologischer Subordinationsverhältnisse, die der semantischen Selektion entgegenstehen" ["a number of curious discrepancies with regard to the morphological subordination relations which contradict the semantic selection"]. At any rate, it remains to be seen "[i]nwieweit es sich hier nur um Kuriosa handelt, oder um Fakten, die eine systematische Beschreibung verdienen" ["whether it's a question of oddities, or of facts which deserve a systematic description"] (Sternefeld 2006: 661).

A more general way of understanding irregularity takes us to the second type of account, namely the approach suggested by Reis (1979), who sees the scandal construction as the result of conflicts among different grammar rules as already pointed out by Bech (1963). In particular, she concludes that these conflicts result from the interaction of simpler constructions but give rise to more complex structures which do not fully correspond to the grammar rules. Nonetheless they are tolerated by the speakers because the latter do not have enough empirical evidence at their disposal to express grammaticality judgements on them. In other words, these structures lie at the borders, in the grey zone of the grammar, and are in this sense un(der)determined.

One cannot but agree with this conclusion, which was already implicitly foreshadowed by Merkes (1895:71), who first observed the scandal construction. At any rate, as pointed out by Vogel (2009), in order to delimit the boundaries of such indeterminacy centring on individual judgements of grammaticality, large text corpora can nowadays be investigated which contain several competing alternatives for the same construction. In fact, as we have seen above, the logical $(7 \mathrm{~d})$ as well as the expected alternative (7c) turned out to be surprisingly less used than the scandal construction. Furthermore, the indeterminacy seems to concern only the three-membered non-finite verbal complexes, while the corresponding finite ones do not present any problem. Clearly, this difference demands a precise grammatical answer and cannot be satisfied by simply making reference to a grey zone.

In this light, Vogel suggests a structural account of the scandal construction which relies on the inner properties of the verbal system. In particular, in an 
Optimality-theoretic framework he sees the construction as resulting from the interaction of several constraints expressing a multiple inadequacy in the formmeaning relations within the verbal complex. This inadequacy is taken as a result of a chain reaction triggered by the occurrence of the IPP. The latter arises as the optimal answer to an alleged restriction forbidding a participle - qualified as a typically governed verb form - to govern an infinitive. This gives rise to a number of readjustments aiming at a better alignment of the selectional restrictions of the verb forms.

Independently of the details, I see three main problems with this explanation. First, it is based on a misunderstanding, or at least an overestimation, of the role of the government relations within the verbal complex, as in other cases a participle governing an infinitive is perfectly justified and never threatened by any readjustment. For instance, in the following example from the Internet there are even two governing participles:

(8) Kurz später kam marshall mit lailah um die ecke gelaufen short later came marshall with lailah around the corner run:PSTPTCP sahaus alswären ${ }_{1}$ die beiden spazieren gegangen $_{3}$ gewesen $_{2}$ ! look:PST:3SG as be:PST:SUBJ:3PL the:PL both:PL walk:INF gone been [http://www.forenfuchs.de/cgi/forenserver/foren/F_1456/cutecast.pl?action =edit\&forum $=15 \&$ thread=49\&msgid $=5 \&$ query $=5$ ]

'Shortly later Marshall came running around the corner with Lailah, he looked as if they had been walking!'

To be sure, it is perfectly possible to imagine a constraint hierarchy accounting for this sequence, although the author does not provide it. However, as is often the case with OT-based accounts, the suggested explanation has a certain ad hoc flavour.

Second, this explanation does not distinguish among the three major types in (7), which display quite a different status both in grammar and in usage. (7d) is the logical type (and indeed quite widespread), (7c) is the expected type (i.e., required by the correspondence with the rest of the verbal complexes requiring an IPP as advocated by Bech 1963) and (7a) is completely unexpected but fairly well attested. In Vogel's approach the three types simply diverge in violating or enhancing different constraints, and the OT framework is considered an appropriate means to derive - i.e. to provide different constraint rankings for - all of them. No attempt is made to provide a hierarchy of adequacy among the types and their respective constraint rankings.

Finally, this account appeals to an alleged constraint on a sequence of three infinitives in the verbal complex, which disfavours the expected type (7c). At any rate, there are other cases in which this constraint does not seem to be relevant, as in the following Internet example: 
(9) Es ist noch nicht viel Schnee, aber er scheint liegen $_{4}$ bleiben $_{3} z$ u wollen . $_{2}$. it is still not much snow:m but he seems lie:INF stay:INF to want:INF [http://mynios.de/2009/12/17/foto-der-woche-51/attachment/51/] 'There is not yet much snow, but it seems to want to stay'.

Again, there surely might be an account for this, but the restriction on the sequence of three infinitives seems to be there ad hoc to account for the IPP. More generally, Vogel's approach completely disregards the diachronic dimension, which arguably has to offer quite a different evolutionary scenario both in connection with the IPP and with the other construction involved, namely the $z u$ infinitive. We will adopt this perspective in the rest of the paper.

\section{Multiple sources for grammaticalization}

One aspect that is seldom the object of linguistic investigation is the expansion of a certain construction once it has been grammaticalized. This aspect should not be dismissed as trivial because, as will be argued below, there may be several different types of distortions showing a non-linear development, which increases the grade of complexity and the number of mismatches occurring in a language (cf. Gaeta 2008). In this sense, I will distinguish the propagation of a certain innovation through a speakers' community from the expansion of a certain innovation through a language grammar (cf. Croft 2000).

Expansion is often referred to in terms of (rule) extension or generalization (cf. Harris \& Campbell 1995:97). Given a certain initial context in which an innovation takes place, the extension refers to the systematic enlargement of the possible contexts displaying the innovation. ${ }^{4}$

To my mind, two different types of expansions must be distinguished, which in turn have to be divided in two further subtypes:

- inner-grammatical expansion

- generalization

- intraference

- cross-grammatical expansion

- interference

- contact-induced grammaticalization

In the first type, we observe the expansion of a certain innovation throughout a language grammar by means of the generalization of the possible contexts in which it turns out to be employed. This takes place generally in accordance with the formula suggested by Himmelmann (2004: 33): 
$\left(\mathrm{X}_{\mathrm{n}}\right) \mathrm{A}_{\mathrm{n}} \mathrm{B}\left|\mathrm{K}_{\mathrm{n}} \rightarrow\left(\mathrm{X}_{\mathrm{n}+\mathrm{x}}\right) \mathrm{A}_{\mathrm{n}+\mathrm{x}} \mathrm{b}\right| \mathrm{K}_{\mathrm{n}+\mathrm{x}}$

where A and B represent full lexical items, $\mathrm{b}$ is a grammaticalized element and the following three types of contextual changes $(\mathrm{K})$ occur:

- Host class formation: $A_{n} \rightarrow A_{n+x}$; e.g. common nouns $\rightarrow$ common and proper nouns.

- Change of syntactic context: $X_{n} \rightarrow X_{n+x}$; e.g. core argument position $\rightarrow$ core and peripheral argument position.

- Change of semantic-pragmatic context: $\mathrm{K}_{\mathrm{n}} \rightarrow \mathrm{K}_{\mathrm{n}+\mathrm{x}}$; e.g. anaphoric use $\rightarrow$ anaphoric and associative anaphoric use.

For our case, the second type of contextual change is of particular relevance, namely the change of syntactic context, as will be discussed in detail below.

Extension or generalization to a new context actually underlies any case of innovation which can be reconducted to grammaticalization as emphasized by Heine \& Kuteva (2007:35). In this regard, they point out that "[g]rammaticalization tends to begin with extension", in particular in the sense that "some speaker (or a small group of speakers) proposes a new use for an existing form or construction, which is subsequently adopted by other speakers". For instance, in the following example drawn from German, Heine \& Kuteva (2007:17) observe that the lexical verb drohen 'to threaten' becomes grammaticalized in the modal usage in (10b) when a non-canonical subject is employed, namely an inanimate noun:
a. Karldroht seinem Chef, ihn zu verklagen.
Karl threatens his:DaT boss, him:ACC to sue:INF
'Karl threatens his boss to take him to court'.
b. Sein Haus droht einzustürzen.
his:NOM house threatens to:collapse:INF
'His house is about to collapse'.

The extension of Haus to the subject position of drohen is connected with a number of pragmatic inferences about the possible interpretation of (10b), which ultimately lead to the reanalysis of drohen as a modal. As argued by Heine \& Kuteva (2007: 18),
"the process started ... when instead of human agents, abstract nouns such as Sünde 'sin', Urteil 'verdict', Gesetz 'law', or Tod 'death' could be used productively as subject referents - in other words when the use of the action verb drohen was extended metaphorically to inanimate concepts conceived as threatening agents".

The usage with inanimate subjects was subsequently generalized rendering vacuous the restriction on the agentive meaning associated with the subject, and forcing the reanalysis of drohen as a modal. 
Independently of the fact that Heine \& Kuteva do not distinguish carefully between the expansion of a rule and its propagation, i.e. its adoption by other speakers, this example is of interest for my purposes because it shows that the starting point of the change presupposes the possibility of using inanimate nouns in the subject position. This points to a high degree of grammaticalization of the syntactic role of subject in German. In fact, if the latter option had not been available, the whole change involving drohen could not have been possible.

My contention is that the extension of the use of inanimate nouns in subject position represents the expansion - in Himmelmann's terms - of the grammatical construction involving subjects throughout the grammar of German. In fact, as is typical of the nominative/accusative languages, the subject position can normally be filled by a wide range of different nouns and noun types. This is much less so in the so-called active languages, in which the subject position - and more generally any syntactic role - is much more sensitive to the semantic properties of the occurring nouns. In other words, syntactic roles are less grammaticalized in active languages. It must be added that Himmelmann's formula also implies that a certain path of expansion has to be followed. For instance, in the case of the grammaticalization of the subject role, it is not to be expected that, ceteris paribus, inanimate nouns are likely to be grammaticalized (i.e. admitted) to the subject role before animate nouns. In my view, such an expansion can be termed linear, because it follows a universal path which naturally reflects a general constraint on grammar. I.e., in our anthropocentric world, it is more natural, simple, unmarked to speak of (animate) agents carrying out actions instead of the opposite, namely inanimate entities being subject to external forces. At any rate, we all know that several deviations, or distortions, from this linear path can be observed, which are to be explained by the effect of other interacting or conflicting tendencies.

The second subtype of inner-grammatical expansion has been labelled by Croft (2000:148) as intraference, but basically refers to the traditional phenomenon of analogy as understood in historical linguistics (cf. Gaeta 2010a for a survey). Croft prefers the term intraference because it focuses on the concept of intralingual identification which is "the recognition of the semantic relatedness of words, inflections and constructions". This allows the speakers to use "a word or construction from the same language ... in a function normally expressed by a different word or construction in that language". Clearly, the distribution of the construction is enlarged, but the mechanism underlying the expansion is partially different from the generalization seen above insofar as one construction turns out to occupy the place of another. We will also benefit from this concept in our treatment of the scandal construction.

The other type of expansion involves more than one single grammar, i.e. it presupposes a context of language contact. In this regard, Croft (2000: 146) emphasizes 
the role played by the interlingual identification, namely "the establishment (possibly temporary) of a cognitive link between the corresponding linguemes [i.e., units of linguistic structure as embodied in particular utterances, LG] of the two languages with respect to their identity in substance".

Two different subtypes are conceivable: on the one hand, traditional interference can be encompassed, whereby the overlapping of one construction of L1 with the corresponding (or with what it is believed to correspond with) construction of $\mathrm{L} 2$ takes place.

The second subtype makes reference to what Heine \& Kuteva (2003) term contact-induced grammaticalization, namely instances of grammaticalization triggered by the contact of L1, in which there is no such construction, with L2, which displays the construction at stake. In our account of the scandal construction, the cross-grammatical expansion is not likely to play any peculiar role, and will be therefore left aside. To be sure, the original development of bare infinitives as well as of the Perfekt construction is largely influenced by language contact, in particular with Latin which served as a Dachsprache during the Middle Ages (cf. Speyer 2001). For our purposes, however, no significant effect is recorded for the more recent times, in which the scandal construction comes to be attested. For this reason, this subtype is not likely to be relevant in explaining the scandal construction.

In what follows, I will argue that the scandal construction results from the intraference which occurred during the generalization of two different source constructions, namely the Perfekt construction and the $z u$-infinitive construction; in particular, when the former construction was being expanded in the context requiring the latter. In fact, the linear expansion of these two constructions happened to come into conflict with each other, as already suggested by Bech (1963). In this light, the scandal construction represents an attempt to solve the conflict resulting from the intertwining of the source constructions. Let us first depict the properties of the two source constructions and then try to understand why the scandal construction can be seen as the response to a conflicting state of affairs.

\section{Two sources for the scandal construction}

The two constructions at stake have quite a long history, which only partially overlaps. From a comparative point of view, it can be added that the two constructions are witnessed in all Germanic languages, although with different properties and source morphemes involved. What is peculiar to German (and more in general to the so-called Continental West Germanic, cf. Zwart 2005 for a survey) is the parallel increment of their diffusion, i.e. propagation in terms of number of occurrences 
and of expansion, i.e. generalization to more and more contexts. Remarkably, this increment characterizes the late medieval history of German and increases as long as we approach the modern age (cf. Betten 1987:115).

In this light, it is not surprising that their parallel development gives rise to interesting side effects like the scandal construction. Let us, in what follows, briefly sketch their history focusing on those aspects which are of particular relevance from the viewpoint of the scandal construction.

\subsection{The Perfekt construction and the IPP}

The first construction at stake in the scandal construction is the so-called Perfekt, which very closely resembles its English cognate. Its grammaticalization can be fairly well reconstructed on the basis of the extant documentation and has to be dated back to the late Old High German (= OHG) period, about the early 11th century (cf. Harris 2003). In fact, it is during this period that the original possessive construction, which had a resultative reading and a past participle agreeing with the direct object (11a), turned out to encode primarily temporal reference, i.e. anteriority, lost agreement of the past participle (11b), and was also expanded to unergative verbs (11c) (cf. Kotin 2000:332 for the exact references):

(11) a. iogiuuelich, thie thar gi-sihit uuib sie zi geronne, iu habet whoever who there gi-sees woman her:Acc to lust he has sia forlegana in sinemo herzen

her:ACC enclosed:PSTPTCP:ACC in his:DAT heart

'Whoever sees a woman in order to lust after her, he'll have already got her enclosed in his heart.'

b. dáz chît síben bûohlísto. dîe unmánige gelírnet this means seven arts which un-many learned:PSTPTCP hábent. úndeáber mánige ge-némnen chûnnen have:PRS:3PL and but many gi-name:INF can:PRs:3PL

'This means the seven arts, which many have studied, but only few are able to mention.'

c. dînen zórn fúrhtendo hábo íhgeuuéinot your:ACC anger fearing:NOM have:PRS:1sG I cried:PSTPTCP 'Fearing your anger I have cried.'

The IPP is first attested two centuries later, and can be encompassed under the general expansion of the Perfekt construction to new contexts in Himmelmann's sense. ${ }^{5}$ In this case, the new context is given by two-membered verbal complexes as they were represented by constructions containing a modal or an AcI-verb, i.e. those verbs which governed a bare infinitive (AcI = Accusativus cum Infinitivo). 
In the 13th century we find instances of the Perfekt construction extended to AcIverbs, thus forming a three-membered verbal complex (cf. Gaeta 2010b: 97 for the references):

(12) daz er die brieffe nit habe ${ }_{1} \quad$ heissen $_{2}$ machin $_{3}$ that he the letters not have:PRS:SUBJ:3sG order:INF make:INF 'that he did not order to prepare the letters'

Notice that this expansion is not attested for the English cognate construction. Three aspects must be emphasized. First, perception and causative verbs represented the favoured domain of employment of the AcI-verbs in early documents. ${ }^{6}$

Second, modals could express anteriority by making use of a past infinitive (cf. Gaeta 2010b: 99 for the references):

daz möht $t_{1}$ ir gerne hân $n_{2}$ verdagt $_{3}$
this can:PST:SUBJ:2PL you:2PL willingly have:INF be-silent:PSTPTCP
'You could have been silent about this with pleasure.

In this case, the Perfekt construction in the form of the past infinitive is applied to the second predicate involved in the verbal complex. However, the occurrence of the modal allows two competing interpretations, which are also found in the English gloss. In the first interpretation, the temporal reference signalized by the past infinitive scopes over the modal and the meaning is similar to that obtained by the construction containing the IPP in (12): 'you have been/were able to be silent'. In the second interpretation, on the other hand, the modal scopes over the temporal reference and the second predicate is modalized as a counterfactual conjecture: 'you could have been silent'. All of this was - and still is - a possible option with modals but impossible with causative and perception verbs, because the latter require the two events predicated to temporarily overlap: ${ }^{\star}$ Er sah sie geschlafen haben 'He saw her having slept'. This still has interesting consequences today, as we will explore below. According to Grønvik (1986:46), the difference accounts for the absence of perfect forms with modals in the earlier attestations: "Daß Perfektformen von modalen Hilfsverben im Mhd. nicht auftreten, rührt also daher, daß man die Perfektbedeutung nicht am Hilfsverb, sondern am Hauptverb ausdrückte" ["The fact that perfect forms of modals did not occur in MHG thus derives from the fact that the perfect meaning was expressed not by the modal, but by the main verb"].

Third, the order $\mathrm{V}_{1[+ \text { finite }]} \mathrm{V}_{2} \mathrm{~V}_{3}$ in subordinate clauses was dominant in early documents, and changed during the 18th century into the modern order $\mathrm{V}_{1[+ \text { finite }]}$ $\mathrm{V}_{3} \mathrm{~V}_{2}$. At any rate, a large amount of variation is documented both in diachrony (cf. Ebert 1999: 123) and in synchrony (cf. Bader \& Schmid 2009 for modern colloquial varieties). It must be added that this deviant order displaying the anteposition 
of the finite member of the verbal complex mainly characterizes constructions containing the IPP as opposed to the other verbal complexes. ${ }^{7}$ The latter generally respond to the verb-final character of German word order in subordinate clauses, as shown by the following examples in which two different four-membered verbal complexes are contrasted:

(14) a. Der Zeuge berichtet, dass dort eine Jugendherberge hat ${ }_{1}$ the witness reports that there a youth:hostel has verwirklicht $_{4}$ werden $_{3}$ können $_{2}$. realize:PSTPTCP become:INF can:INF 'The witness reports that a youth hostel could be realized there.'

b. Der Zeuge berichtet, dass dort Jugendliche geschlagen ${ }_{4}$ the witness reports that there young:PL beat:PSTPTCP worden $_{3} \quad$ sein $_{2}$ sollen $_{1}$ become:PSTPTCP be:INF shall:PRs:3PL

'The witness reports that young persons are supposed to have been beaten there.

As for the reasons why such a peculiar linearization has been preserved (and even extended, as witnessed by the future construction) in modern German, the opinions diverge. Ágel (2001) finds three constant diachronic tendencies corresponding to three conflicting principles that can be made responsible for the actual development, while Eisenberg, Smith \& Teuber (2001) insist on the peculiar character of the linearization displayed by the constructions containing the IPP. The different linearization is taken to be an explicit property that characterizes the constructions containing the IPP with regard to the rest of the other verbal complexes.

At any rate, independently of what the correct interpretation of the deviant linearization should be, it turns out that two opposite paths have to be followed to interpret the German verbal complex, namely from right to left (R-to-L) and from left to right (L-to-R):

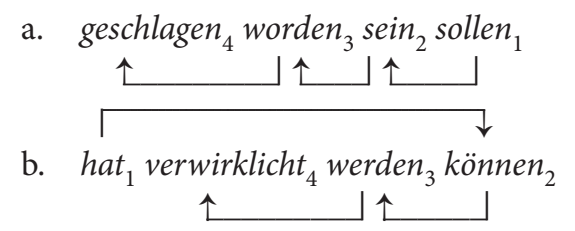

Notice that, while the R-to-L path also stands alone and is therefore unmarked (15a), the L-to-R path only occurs in the presence of its R-to-L counterpart (15b). As observed above in (12), the L-to- R path in the absence of any R-to-L counterpart was the dominant option in the older attestations (and is still attested in 
other West Germanic varieties as for instance in Dutch, as well as in other German dialects, cf. Schmid \& Vogel 2004). In the light of the actual markedness of the L-to-R path and of its obligatory occurrence in combination with an IPP, we can characterize the latter with the help of the presence of the two-directional path. Moreover, it has to be emphasized that the L-to-R path generally moves from the fore-standing auxiliary haben to the IPP. We will see below that these two properties, i.e. the two-directional path and the auxiliary haben as a starting point for the L-to-R path are of crucial importance in explaining the scandal construction.

\subsection{The generalization of the $z u$-infinitive construction}

Let us pass to the other source construction involved in the scandal, namely the $z u$ infinitive construction. The latter has been fairly well investigated (cf. Haspelmath 1989, Gaeta 1998, Demske 2001, Abraham 2004). In brief, in OHG, besides the AcI-verbs seen above, so-called "bare infinitives" occurred exclusively after other verb types such as modals and raising verbs (cf. Demske 2001:74-75 for the references):
a. ther sich thes muaz frowon who himself this:GEN:SG must:PRs:3sG enjoy:INF 'who is able to enjoy this'
b. Tannân skînet offeno ein ding uuesen therefore seems manifestly a thing be:INF 'Therefore there clearly seems to be one thing.'

The bare infinitives were already in competition with the construction constituted by the allative preposition $z u$ in combination with the infinitive (also marked by the dative case), similarly to what happened to its English cognate to plus infinitive (cf. Fischer 1994). As shown by Haspelmath (1989), this quite common grammaticalization process, whereby the verbal infinitive results from the grammaticalization, or possibly the reinforcement, of allative constructions containing a verbal noun, was taking its first steps in OHG. In fact, it was used in the early OHG sources mostly with infinitives encoding a final-purposive content and was paralleled by the occurrence of bare infinitives as well. For instance, an aspectual verb like bigannan 'to begin' only appears in combination with the bare infinitive in the early OHG documents, while it also displays the $z u$-construction in late OHG (cf. Schrodt 2004: 4 for the references):

(17) a. Tho bigan er wuafan, zu druhtine ruafan then began he complain:INF to lord:DAT call:INF 'Then he began to complain, to invoke the Lord.' 


\section{b. uuara ih dih pegunnen habo zeleitenne where I you:ACC:SG begun have:1sG to lead:INF:DAT 'where I have begun to lead you'}

Furthermore, sentence pairs can be mentioned in which the verb gisehan, which displays two possible readings (1. 'to see'; 2. 'to watch, to look after'), selects in one case the bare infinitive when the latter has no final interpretation (18a), while in the other case a $z u$-infinitive with a final content is employed (18b) (cf. Demske 2001:76 for the references):

\section{a. mittiu ir gisehet Abrabam inti Isaac inti Iacob inti} when you:PL gi-see:2PL Abraham and Isaac and Jacob and alle uuizogon ingangan in gotes richi all:PL prophets enter:INF in God:GEN kingdom 'when you will see Abraham and Isaac and Jacob and all the Prophets enter into the kingdom of God'

b. aruuirph zi heristen balcon fon thinemo ougen, thanne gisihis take:out zu first rafter from your:DAT eye:DAT, then gi-see:2sG thu zi aruuerphanne fesun fon thines bruoderougen you:SG to take:out:INF:DAT straw from your:GEN brother eye:DAT 'first take out the rafter from your own eye, then you will see how to take out the straw from your brother's eye'

Later on, a generalization of the $z u$-infinitive construction took place, so that in the modern language it covers almost the whole spectrum of subordinate infinitives, including for instance those governed by raising verbs:

(19) Unser Hund scheint offensichtlich erkrankt ${ }^{*}(z u)$ sein. our dog seems clearly diseased to be:INF 'Our dog clearly seems to be ill.'

Nonetheless, as we have seen above in Section 2, the modals as well as the two perception verbs hören and sehen and the causative verb lassen still resist the generalization of the $z u$-infinitive construction, and instead preserve the construction with a bare infinitive. Furthermore, a number of other verbs also admit the bare infinitive construction nowadays. However, the $z u$-infinitive is also possible on condition that the latter occurs in sentence-final position:

(20) a. Hans glaubt, dass Inge gerne Russisch sprechen lernen $_{2}$ Hans thinks that Inge gladly Russian speak:INF learn:INF möchte ${ }_{1}$. like:PST:SUBJ:3sG

'Hans thinks that Inge would really like to learn Russian.' 
b. Hans glaubt, dass Inge gerne lernen möchte $_{1}$, Hans thinks that Inge gladly learn:INF like:PST:SUBJ:3sG Russisch ${ }^{\star}(z u)$ sprechen $_{3}$. Russian to speak:INF 'Hans thinks that Inge would really like to learn Russian.'

In fact, the generalization of the $z u$-infinitive construction goes hand in hand with the establishment of the sentence-final - so-called incoherent - position that is dominant in modern times, but was far from being fixed in the 13th century (21a-b) (see Askedal 1998 for the references), or later in the 16th (21c) and the 17th centuries (21d) (see Ebert 1999: 154, 157 for the references):

(21) a. diu zît, die uns got zu leben hât $_{1}$ gegeben $_{2}$ the time which us God to live:INF has given 'the time which God has given us to live'

b. die zît, die dî zebrennen verdienen $_{2}$ hâst ${ }_{1}$ the time which you:SG to burn:INF deserve:INF have:PRS:2SG 'the time which you have deserved to burn'

c. Nunhon ichminen gaistlichen kinden now have:PRS:1SG I my:PL:DAT spiritual:PL:DAT children:DAT verhaissen $_{2}$, uffhútt inen etwas zusagen von $_{3}$ promise:PSTPTCP up today them:DAT something to say:INF of fruchtberkait und nutz gedultigs lydens fecundity und profit patient:SG:GEN suffering:GEN 'Now I have promised my religious children to say something about the fecundity and the utility of the patient suffering.'

d. wollen $_{1}$ wir/davon zu reden $/$ auf want:PRS:1PL we about:this to talk:INF up folgenden Theil versparen following:SG:ACC part postpone:INF 'we want to postpone talking about this until the following part'

What characterizes modern word order is the sentence-final position of the first infinitive governed by the main verb and immediately preceded by $z u$. For our purposes, it must be emphasized that this order follows the R-to-L path: the sequence involved in a verbal complex follows that order in harmony with the dominant verb-final character of German:

(22) a. Hans scheint, gerne Russisch sprechen lernen $_{3}$ zu wollen . $_{2}$ Hans seems gladly Russian speak:INF learn:INF to want:INF 'Hans seems to really want to learn Russian.' 
b. Der Zeuge berichtet , $_{\text {, dort von Jugendlichen geschlagen }}$ the witness reports there by young:PL beat:PSTPTCP worden $_{3} \quad z u \operatorname{sein}_{2}$. become:PSTPTCP to be:INF

'The witness reports having been beaten there by young persons.'

The dominant verb-final character of German is also reflected by the fact that a verbal complex containing more than one $z u$-infinitive construction normally complies with the R-to-L path:

(23) Unter praktischer Hilfeleistung verstehe ${ }_{1}$ ich nicht, jemand under practical help understand I not someone anderen von etwas $\quad z u$ überzeugen ${ }_{3} z$ u versuchen ${ }_{2}$. other of something to convince:INF to try:INF http://www.forum-treffpunkt-leben.de/650714-post25.html 'Under concrete help I don't mean to try to convince anyone else of anything.'

However, this is not obligatory, and an L-to-R sequence is also possible, and even preferred, as long as the number and the size of the embedded verbs increase:

(24) Also musste ich ja noch warten und hatte ${ }_{1}$ genügend Zeit meine thus must:PAST I yes still wait and had:PAsT enough time my Eltern zu versuchen ${ }_{2} z$ überzeugen ${ }_{3}$ oder mehr oder weniger zu überreden ${ }_{3}$. parents to try:INF to assure:INF or more or less to persuade:INF http://lisa-america.de/category/der-weg-bis-zu-into/ 'So I still had to wait and I had enough time to try to assure or more or less persuade my parents.'

When this occurs, the $z u(\mathrm{~s})$ can be omitted except for the last one, i.e. the one which occupies the penultimate sentence position (in some varieties like Bernese or Austrian German this type with omission of the $z u$ is even preferred except for the last one, cf. Abraham 2004: 121).

(25) a. Er scheint versuchen $_{2}$ zu schlafen se $_{3}$ während der he seems try:INF to sleep:INF, while the Rocksong richtig losgeht. rock song right gets started http://rhapsode.wordpress.com/filmanfange-iii-1973/

'He seems to be trying to sleep just as the rock song really gets started'.

b. Da scheinen Verwandte und Freunde versucht $_{3}$ haben $_{2}$ there seem:PRES relatives and friends tried:PSTPTCP have:INF zu pushen . $^{\text {. }}$ to push:INF 
http://www.lovelybooks.de/thema/Wie-geht-man-als-Autor-mitnegativer-Kritik-um--579244163/

'Relatives and friends seem to have tried to push it.'

Notice that the omission of $z u$ affects verbal sequences containing both present and past infinitives. The categorial status of $z u$ has been hotly debated, namely whether it is to be considered a bounded morpheme and specifically a phrasal prefix as assumed by Vogel (2009), or a complementizer as more traditionally assumed by Ebert (1976:81) \& Demske (2001), or, finally, an infinitival preposition as pleaded by Abraham (2004). Independently of this question, the examples in (25) clearly show firstly that the privileged position of $z u$ is the penultimate one. Secondly, the government relation with the finite verb need not be expressly marked: the $z u$ which is connected with the immediately governing verb is in fact dropped. This is true both of (25a), in which a strictly L-to-R path is adopted, and of (25b), in which the occurrence of a past infinitive requires first an R-to-L path followed by a L-to-R path.

While the omission of $z u$ contributes to the conventionalization of the construction, its occurrence in the penultimate position of the sentence suggests that the non-finite verbal complex might be interpreted as a partially specified constructional idiom [V ...zu V\#] in the sense of Goldberg \& Jackendoff (2004). This is not entirely compositional and has to be processed holistically. In fact, the governance relations are made opaque by dropping the $z u$. In this light, the question of its syntactic relevance as a marker of the governance relation between the verbal complex and the finite main verb loses relevance, because its role turns out to consist in delimiting the boundary of the verbal complex insofar as it signals that the last member of the verbal complex is about to come. In a way, this conclusion parallels Bech's (1963) view discussed above with regard to the "violent solution" forcing the detachment of $z u$ from its governee. We will see below that this creates the conditions for the scandal construction to occur.

5.3 The intertwining of the two source constructions and the scandal

With this background in mind, let us now go back to the scandal construction that is reported below:

(1) Hans bedauert, es nicht verhindert ${ }_{3} \quad$ haben $_{1}$ zu können $_{2}$. Hans regrets it not prevent:PSTPTCP have:INF to can:INF 'Hans regrets not having been able to prevent it.' 
The discussion of the previous section has shown that in three-membered verbal complexes a constructional idiom [ $\mathrm{V} \ldots z u \mathrm{~V} \#]$ comes about in which $z u$ turns out to function as signal for delimiting the right margin of the verbal complex.

A similar conclusion is also suggested by the expected construction in (4) above, which represents the natural (i.e., in the terms adopted in Section 4: linear) expansion of the IPP construction to the context requiring the $z u$-construction:

(4) Hans bedauert, es nicht haben ${ }_{1}$ verhindern ${ }_{3}$ zu können ${ }_{2}$. Hans regrets it not have:INF prevent:INF to can:INF 'Karl regrets not having been able to prevent it.'

Moreover, recall that no direct link syntactically connects $z u$ with the following IPP.

In other words, in these constructions, the same constructional idiom [V ...zu $\mathrm{V}_{\text {inf }}$ \#] occurs, in which a partial opacity of the whole is balanced by $z u$ signalling the boundary of the verbal complex. In this regard, Merkes (1895:67), discussing an example like Er scheint den Brief geschrieben haben zu können 'He seems to be able to have written / to have been able to write a letter', foreshadows the concept of a constructional idiom requiring a holistic interpretation:

"Hier steht $z u$ immer vor dem letzten Worte des Satzes, und diese Stellung drängt sich dann leicht dem Sprachgefühl, ohne daß man dessen bewußt würde, als Regel auf, und erscheint dann auch in Fällen, wie die obigen: wenn man ohne kritische Zerlegung des Gesagten über dem Gedanken die Form vergißt"

["Here $z u$ is always placed before the last word of the sentence, and without being aware of it, this position imposes itself as a rule upon one's feeling for the language, and then subsequently appears in cases like those above as well: when - in the absence of a critical breakdown of what has been said - one forgets the form in favour of the thought."] (my translation).

Besides the role of $z u$, the occurrence of the two-directional path in the scandal construction does not surprise us anymore in light of what we have seen above in Section 5.1:

(26)

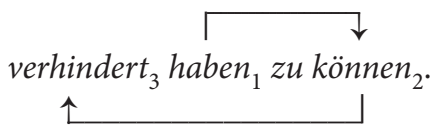

In fact, the two-directional path clearly signals the presence of an IPP. Moreover, as testified by the logical sequence in (2) above and reported below in (7d), it disappears in favour of the unmarked R-to-L path when no IPP occurs. Notice that, when the IPP is found in the other possible variants of the construction as they are summarized in $(7 \mathrm{a}-\mathrm{c})$ below, the two-directional path also shows up as expected: 
(7) a. ... verhindert haben $_{1}$ zu können

b. ... verhindern haben $_{1}$ zu können $_{2}$

c. .... haben verhindern $_{3}$ zu können 2

d. $\quad$.. verhindern gekonnt $_{2}$ zu haben $_{1}$

Finally, the most striking property of the scandal construction in (7a) is the content mismatch which maps an expected participle (that surfaces as an IPP) onto an expected infinitive (that in fact surfaces as a past participle). This participle only occurs immediately before the form haben, i.e. when it forms a theoretically possible - even though contextually inappropriate - verb form, namely a past infinitive. In fact, this apparent past infinitive manifests itself only because haben is placed in second position in contrast with the expected initial (7c) or final (7d) placement:

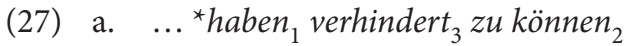

b. $\quad . \quad{ }^{*}$ verhindert $_{3}$ gekonnt $_{2}$ zu haben 1

However, the past infinitive is not contextually justified and the correspondence is merely superficial. It is natural to suppose that this fact is not casual and may provide the key for understanding the scandal construction.

In fact, in the light of the nonsensical mapping, one plausible explanation is that it results from what we have called "intraference" above, adopting Croft's (2000) term. Recall that the latter refers to the fact that "[d]ifferent elements of the same language can interfere with each other if they share enough linguistic substance, in particular meaning" (Croft 2000:148). The crucial factor underlying the intraference is a process of "intralingual identification" which is responsible for "the recognition of the semantic relatedness of words, inflections and constructions" (Croft 2000: 148).

The intralingual identification allows the extension of a certain construction beyond its original domain even though the extension is only partial. A partial extension of a certain pattern gives the impression of an illogical change, as is often the case with the typical contaminations which generally result from a nonproportional analogy (cf. Hock 1991:197, Gaeta 2010a among many others). Hermann Paul [1920] (1995: 163) already emphasized that contamination plays a major role in syntactic change, and the attempts to disregard this role simply misunderstand the essence of contamination as a distinct phenomenon. One classical example pointed out by Paul [1920] (1995: 165) concerns the following construction witnessed by Goethe's famous ballad Ich hab mein Sach auf nichts gestellt:

(28) a. Und mein gehört die ganze Welt and mine belongs the whole world 'And to me belongs the whole world.' 


\section{b. mir gehört die ganze Welt me:DAT belongs the whole world \\ c. mein ist die ganze Welt mine is the whole world}

The construction in (28a) results from the contamination or intraference of (28b) and (28c). Harris and Campbell (1995:118) contend that "[a]ll examples of 'contamination' that we know of are analyzable as examples of extension", but this cannot be true for our understanding of extension as generalization. In fact, in (28a) we simply do not have an extension of the argument structure of sein 'to be' to the verb gehören 'to belong'. Much more, a real intertwining of the two constructions has taken place, violating the selectional properties of the predicates to such an extent that a possessive pronoun turns out to be the argument of a verb, which is generally excluded. It has to be emphasized that the crucial factor influencing the contamination is their shared substance of meaning, to use Croft's terms, which favours intralingual identification.

Coming back to the scandal construction, its inconsequentiality suggests that it might result from the intertwining of two overlapping source constructions via the intralingual identification of their similar parts that also share substance of meaning.

In this light, two candidate constructions are required which should be similar enough to trigger the intralingual identification. The first candidate might be what we have called the expected construction in (7c). Recall that this construction had the property of crucially preserving the two-directional path characterizing the IPP construction, while at the same time the cost paid was the detachment of $z u$ from its direct infinitival governee. By doing so, $z u$ also acquired a delimiting function, signalling the right margin of the verbal complex.

As for the second candidate, we have seen that in three-membered verbal complexes also involving a past infinitive the first $z u$ may be dropped (see (25) above). It must be added that this sequence is also common when the finite verb consists of a modal:

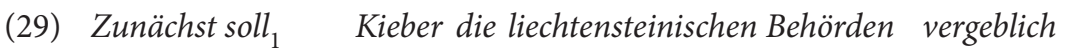
initially shall:3sg Kieber the Liechtenstein authorities in vain versucht $_{3}$ haben $_{2}$ zu erpressen . . try:PSTPTCP have:INF to blackmail:INF http://de.wikipedia.org/wiki/Liechtensteiner_Steueraff\%C3\%A4re 'Kieber is supposed to have initially tried to blackmail in vain the public authorities of Liechtenstein.' 
The constructions in (25) provide a formal model similar to that characterizing the IPP construction in (7c), because in both cases the role of $z u$ amounts to delimiting the right margin of the verbal complex, which qualifies them as constructional idioms:

(30) a. ...haben verhindern $_{3} z$ zünnen k $_{2}$

b. ... versucht haben $_{1}$ zu pushen $_{3} \#$

In this light, it is natural to assume that the intralingual identification takes as an anchor the penultimate position occupied by $z u$ and the similar final infinitive. This identification favours the overlapping of the rest, as depicted in the following figure:

(31)

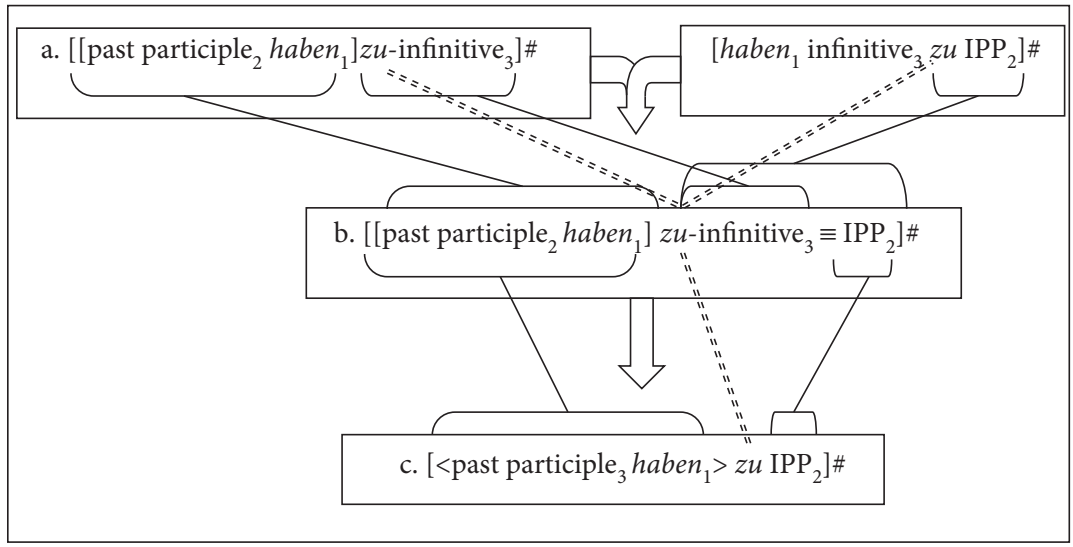

The initial intralingual identification is represented in (31b) by the identification of the final chunk of the two constructional idioms in which $z u$ plays the role of a fixed anchor. The appearance of the initial past participle is enforced by the model in (30b), in which the past participle is morphosyntactically appropriate as indicated by the square brackets. The trigger provided by the intralingual identification leads to the reanalysis of the verbal complex in terms of the scandal construction in (31c). Notice that after the intraference the two-directional path typically characterizing the occurrence of the IPP in (30a) is preserved at the expense of the direct connection of the two verb forms building the past infinitive of the model in (30b). I will come back to the angle brackets of (31c) below.

This reanalysis might also have been favoured by the presence of a modal which, as we have seen in Section 5.1, triggers processes of reanalysis forcing the temporal feature to scope over the modal. In this regard, consider the example (32a) from the Internet in which the last infinitive consists of a modal: 
a. Ich habe das letztes Jahr noch nicht gewußt und

I have:PRs:1sG this last year yet not know:PSTPTCP and es quält mich sehr mit meinem Mann nicht diese it bothers me:ACC very with my:DAT man not this Chance zumindest probiert haben $_{2}$ zu können ${ }_{1}$ chance at:least try:PSTPTCP have:INF to can:INF http://www.krebs-kompass.de/showthread.php?t=687

'Last year I did not know this yet and it really bothers me to be not able to have at least taken this chance with my husband.'

b. ... diese Chance zumindest probiert haben $_{1}$ zu können h $_{2}$ this chance at:least try:PSTPTCP have:INF to can:INF '... to have not been able to take this chance'

In this example, the final modal of the verbal complex which has a dynamic interpretation may have semantic scope over the perfective representation of the event involved, similarly to what we have seen in the MHG example in (13) above. In this regard, Merkes (1895:72) had already suggested treating the scandal construction as a mistake whereby the speaker "den Perfektbegriff aus dem modalen Hülfsverb, das ihm Schwierigkeiten bot, in den obliquen Infinitiv verlegte: und dies ist weiter nichts als ein Nachwehen des mittelhochdeutschen Sprachgeistes" ["shifted the concept of the perfect from the modal auxiliary, which presented difficulties to him, to the oblique infinitive: and this is nothing other than an echo of the Middle High German linguistic spirit"]. Although this view cannot be maintained, we may nevertheless observe the contact point between the old and the modern construction.

In fact, in contrast to MHG, the full grammaticalization of the Perfekt construction, which primarily encodes past tense, favours the enhancement of the temporal over the aspectual dimension. This is reflected in the shift observed in (32b), in which the past tense scopes over the modal, probably because the event involved is interpreted as perfective or bounded in both cases. The latter case with the past tense scoping over the modal is also extended to those cases in which the modal should scope over the perfective event. This conceptual shift forces an implicit reanalysis of the verbal sequence as given in (32b), in which the modal is treated as an instance of the IPP and the rest is adapted in accordance with the intraference model seen above: ${ }^{8}$

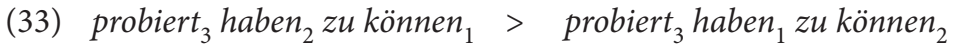

While in the examples $(32 \mathrm{a}-\mathrm{b})$ the shift from modal > past tense to past tense $>$ modal remains an open choice, in other cases the shift is contextually required. This reinforces the contaminated construction, as in the following Internet example, in which the past tense has clearly scope over the modal: 
(34) Manche Lehrer berichten davon, circa 10 Minuten lang gewartet many teachers report of:this ca. 10 minutes long wait:PSTPTCP haben zumüssen, bis die Lerngruppe ihr Gegenüber have:INF to must:INF until the learning:group their counterpart wahrgenommen hat. perceive:PSTPTCP has http://tellkampfschule-h.nibis.de/site/index.php?option=com content\&view $=$ article\&id=23\&catid=16\&Itemid=29\&showall $=1$ 'Many teachers report having had to wait 10 minutes before the learning group realized their counterpart'.

Finally, when a causative verb like lassen is involved, the conceptual shift is no longer a possibility but a necessity:

a. grundsätzlich würde ich kein Instrument kaufen, ohne es basically become:PST:SUBJ I no instrument buy:INF without it vorher ausprobiert zu haben, bzw. es von jemandem probiert before try:PSTPTCP to have:INF or it by someone try:РSTPTCP haben zulassen, der sich damit auskennt. have:INF to let:INF who himself with:this knows http://www.wer-weiss-was.de/theme213/article3153617.html 'I would generally not buy an instrument without having tried it before, or having it tried by somebody who knows it well.'

b. Zehn Minuten später entschloss sie sich, ihn genug ten minutes later decide:PST she herself him:ACC enough gewartet haben zulassen wait:PSTPTCP have:INF to let:INF http://notrufhafenkante-ig.de/board83-notruf-hafenkante-fanarts/ board92-fanfictionecke/board101-beendet/703-die-zeit-die-bleibt/ index6.html

'Ten minutes later she decided that she made him wait long enough.'

In these cases, an interpretation in which the causative scopes over the past in-

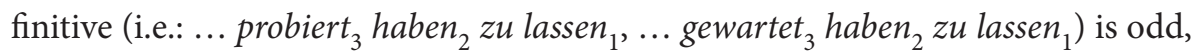
while the other interpretation reflecting the past tense scoping over the modal

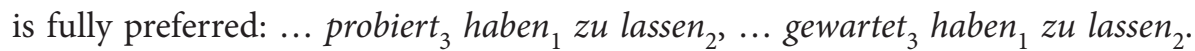
Clearly, the latter interpretation expressly mirrors the structure of the scandal construction.

The intraference depicted in (31) above provides the answer to what is probably the oddest property of the scandal construction. Although no direct relation occurs between the past participle and the auxiliary haben, the scandal construction has to respect the strong morphosyntactic condition that the sequence has to be 
theoretically possible, i.e. well-formed as a potential unit, as indicated by the angle brackets in (31c). ${ }^{9}$ In fact, when the latter condition is not respected, the scandal construction is not possible and the expected type (7c) has to be used instead:
a. ${ }^{\star}$ Hans bedauert, allein ausgegangen haben $_{1} \quad z u$ müssen $_{2}$.
Hans regrets alone go:out:PSTPTCP have:INF to must:INF
b. Hans bedauert, allein haben ausgehen $_{3}$ zu müssen . $^{\text {. }}$
Hans regrets alone have:INF go:out:INF to must:INF
'Hans regrets having had to go out alone'.

The sequence ${ }^{*}<$ ausgegangen haben $>$ does not constitute a well-formed potential unit because ausgehen selects sein 'to be' as an auxiliary to form the past infinitive: <ausgegangen sein>. ${ }^{10}$ This restriction is fairly well explained by the direct influence exerted by the model in (30a) during the intralingual identification. Without the intervention of the intraference, this property remains completely mysterious. Furthermore, the occurrence of haben in the penultimate position is also compatible with the activation of the two-directional path which generally characterizes the occurrence of the IPP as shown by (15b), and is also found in the expected construction of (7c).

Finally, one may wonder why this intraference took place in spite of the existence of, for instance, the expected construction, which might have been generalized by the speakers because it is the norm with finite verbal complexes. I suggest two possible answers. The first one has to do with the role of the constructional idiom [ $\mathrm{V} \ldots z u \mathrm{~V} \#$ ], as already foreshadowed by Merkes (1895). As emphasized by the constructionist framework (cf. Bybee 2006 among others), such abstract, partially specified models may be quite robust and have effects on similar structures because of their lexical entrenchment. It is interesting to observe that the intraference gives rise to a new construction displaying a surface property, i.e. the well-formedness of the initial past infinitive, which does not follow the real interpretation of the chunk.

The second answer leads us to Haider's (2011) issue on acceptable but ungrammatical sentences. In fact, this deviant structure surely reveals the speakers' uncertainty in combining long sequences of embedded infinitives. In this light, the grammaticality judgements, as already pointed out by Reis (1979), may become vague and allow for several alternatives. This vagueness can be made partially responsible for the contamination.

However, I cannot share Haider's general approach in which grammaticality is kept neatly separate from acceptability. Accordingly, the scandal construction would be acceptable (and indeed widely attested), but ungrammatical, a sort of grammatical illusion similar to the optical illusions in visual processing, in this way re-proposing Sternefeld's conclusion on its basically irregular character. ${ }^{11}$ 
Furthermore, Haider (2011) suggests a different solution to the puzzle of the scandal construction, which shares some idea with the one suggested here. He considers the intraference to be due to the typically South-Eastern linearization of the verbal complex which sounds like type (7b): ... verhindern haben $_{1}$ zu können $_{2}$. On this basis, haben is taken by mistake to be the "Auslöser der Partizipialform des vorangehenden Verbs" ["trigger of the participial form of the preceding verb"]. In this way, Haider recognizes the role played by morphology in driving the intraference, because the morphological well-formedness of the verbal sequence is required, as shown by the ungrammaticality of (36) above. However, one major problem of this account is that it crucially relies on the sequence ... verhindern ${ }_{3}$ haben ${ }_{1} z u$ können $n_{2}$ which Haider claims to be the normal linearization of the verbal complex. But the data documented by Vogel and reported above in (7) do not support Haider's claim, although it might be correct for his own variety of German. In fact, it appears only in a few cases containing the causative verbs lassen. This casts doubts on Haider's account, because it leaves unexplained why such a type is so scantly attested and only appears with lassen.

Moreover, Haider sees evidence in support of his view in the following example already pointed out by Reis (1979) in which a verbal complex similar to the scandal construction occurs:

Eine Pariserin namens Dimanche soll sich ein gewaltiges Stirnhorn a Parisian:F named Dimanche shall:3sg herself a huge front:horn operativ entfernt haben lassen operational excise:PSTPTCP have:INF let:INF 'A Parisian woman called Dimanche is likely to have had a huge frontal horn excised.'

Notice that in contrast with the scandal construction, this verbal complex does not contain the $z u$-infinitive. This apparently supports Haider's (2011:232) approach because the verb form haben, the alleged trigger of the intraference, appears in the bare infinitive form "ohne seine Markierung als übergeordnetes Auxiliar" ["without its marker as higher-ranking auxiliary"], namely $z u$. However, when the latter is the case, namely for instance when haben appears in the finite form, the ungrammatical but acceptable construction should be predicted to disappear. Unfortunately for Haider, the latter is not true, and the scandal construction is also found when the last verb consists of a finite form, as shown by the following Internet example, which can be easily multiplied: 
(38) Für jegliche Empfänger dieser Email die vor kurzer Zeit sich for those receivers this:GEN e-mail who before short time themselves von unserer Emailliste entfernt haben lassen, werden of our e-mail-list cancel:PSTPTCP have:INF let:PRS:3PL become:PRS3PL keine weiteren Werbe-Emails von Ascentive gesendet no further advertisement-emails of Ascentive send:PSTPTCP http://www.ascentive.com/de/about_us/press091216_autorenew.html 'To those receivers of this e-mail who recently had themselves removed from our mailing list, Ascentive will not send any further advertising e-mails.'

In the approach defended here, both cases can be explained away as extensions of the scandal construction as long as it is established as suggested by the data in the table in (7) above. Notice that most of these (extended) examples involve the causative verb lassen, which has been already observed above to display peculiar behaviour deserving a separate treatment that cannot be afforded here. Moreover, the role of the verbal complexes headed by a finite modal was mentioned above in (29): this also favoured the intralingual identification leading to the intraference.

\section{Conclusion}

To sum up, the history of the two source constructions discussed in the paper, namely the Perfekt construction with its possible variants and the $z u$-construction, reveals an unexpected result, namely their intraference which gives rise to a complex form-meaning mismatch. Probably, this intraference has to be seen as the answer found by German speakers to master the complex picture resulting from the expansion of verbal periphrases like the Perfekt construction, the AcI-construction including the IPP, and the $z u$-construction.

This intraference fits fairly well into a constructionist model of language, which crucially relies on the concept of lexical entrenchment. In this case, the building block favouring the intralingual identification is given by the partially specified constructional idiom $\left[\mathrm{V} \ldots z u \mathrm{~V}_{\text {inf }} \#\right]$ in which an overlap of the final sequence of two different source constructions containingthe Perfekt construction and the IPP-construction, respectively, takes place. Moreover, a reanalysis of the scope of the modal interferes with the complex two-directional path accompanying the construction containing a final IPP.

As a crucial piece of evidence in support of this view, the construction resulting from the intraference inherits the purely surface condition whereby the morphologically licensed verb form of the $<$ past infinitive $>$ has to be activated as a filter for checking the well-formedness of the first two members of the verbal complex. This is possible only if the verb form $<$ past infinitive $>$ is somehow represented as 
an abstract model in our mental lexicon, and accordingly able to scan and filter out those concrete sequences which do not match the abstract model, as is the case of ${ }^{*}<$ ausgegangen haben $>$ discussed above. From a general perspective, this constraint is interesting because it shows that abstract constructions like <past infinitive $>$ have an influence on what we observe on the surface, even at the level of merely potential sequences.

In sum, the expansion of the different source constructions gave rise to recurrent surface patterns which were taken to be more reliable than what the logical combination of the single pieces of the verbal complex should have given rise to. The story of the scandal construction tells us that these recurrent patterns may be separated from their content words and become abstract models which are easier to process and accordingly extended to other content words, even if the latter are not immediately to be fitted into the abstract models. Constructions don't care about scandals.

\section{Notes}

* I am deeply indebted to Ralf Vogel and one anonymous reviewer for helpful comments and suggestions. Moreover, I would like to thank the editors of the volume for their patience, and Martina Della Casa for checking my English. Needless to say, I take full responsibility for any errors in the paper.

1. Following a well-established tradition (cf. Bech 1955/57), the subscript numbers make reference to the level of subordination of the members of the verbal complex. Moreover, in contrast to the common German usage, I will use the term verbal complex in this paper to make generic reference to any kind of sequence containing more than one verb form. In particular, I will not enter into the question of the so-called Satzwertigkeit 'sentence-equivalence' of non-finite verbal complexes. See Askedal (1998) and Haider (2003) for a discussion. In the paper, the following abbreviations are used: ACC $=$ accusative, $\mathrm{DAT}=$ dative, $\mathrm{GEN}=$ genitive, $\mathrm{INF}=$ infinitive, $\mathrm{NOM}=$ nominative, $\mathrm{PL}=$ plural, $\mathrm{PRS}=$ present, $\mathrm{PST}=$ past, $\mathrm{PSTPTCP}=$ past participle, $\mathrm{SG}=$ singular, $\mathrm{SUB} \mathrm{J}$ = subjunctive.

2. Actually, it is not clear whether the deviant linearization should be attributed to a content mismatch. In my view, this is justified by the reference to an arguably "logical" place to be occupied by a certain morpheme in the grammar. The reference to logic implicitly implies content. On the other hand, it might also be that this type of mismatch involving the linearization of morphemes should be treated as a different kind of incongruent mapping, thus qualifying for a third, separate type of "place mismatch". This question is left open for further research.

3. See fn. 5 below. Moreover, I leave aside here the case of language contact, which also has the effect of limiting the expansion of a grammaticalization change. See Gaeta (2008) for details.

4. Harris \& Campbell's view of rule extension has been criticized because they try to defend the idea that rule extension can always be formulated by making reference to natural contexts 
of extension. In the face of cases not easily described in terms of natural contexts, however, they simply explain them away as exceptions, which makes their account at least weak, if not circular (see Croft 2000: 154-155). I prefer the term expansion because both extension and generalization seem to hint at a relaxing of the conditions governing the employment of a certain construction, which is not necessarily true.

5. In Gaeta (2008, 2010b), the occurrence of the IPP has been treated as an instance of an imperfect change during the process of expansion of the Perfekt construction due to a number of reasons that cannot be discussed here. For the purposes of the present paper, the reconstruction of this historical scenario can be left in the background.

6. Although in modern times the issue mainly concerns modal verbs, it has been shown that causative and perception verbs are the first set of AcI-verbs which were combined with the Perfekt construction, while modal verbs begin to appear later (cf. Eroms 2006, Gaeta 2010b for details).

7. Interestingly, this linearization is also to be found optionally with the future construction, which involves the auxiliary werden 'to become'. I cannot explore the implications of this fact here. For more details see Gaeta $(2008,2010 b)$.

8. As suggested by one anonymous reviewer, an invited inferencing of the type proposed by Traugott \& Dasher (2002:34-40) might be going on here. However, the problem is made intricate by the interaction with the IPP-construction and cannot be discussed at length here.

9. Similar observations on this morphosyntactic condition have been made both by Vogel (2009:312) and Haider (2011), but only the latter draws relevant conclusions from this property which will be discussed below.

10. As observed by one anonymous reviewer, the auxiliary sein is also possible here giving rise to a sequence like the following (example from the Internet):

(i) Dankbar bin ${ }_{1}$ ich fürdiese Möglichkeit, diesen Weg überhaupt gegangen sein $_{3}$ grateful am I for this possibility diese:ACC way at all gone be:INF zu können . $^{2}$

to can:INF

http://marianneglobal.blogspot.fr/2012/08/bodensee-gut-alles-gut-kapitel-iv.html 'I am grateful for this possibility to be allowed to have gone this way at all'.

However, this verbal complex behaves in a radically different way with respect to the scandal construction inasmuch as it does not contain any IPP nor does it allow the reanalysis of the past tense scoping over the modal as discussed in (32) above.

11. One major problem of Haider's antithesis between grammaticality and acceptability comes from language change which, as we have seen above discussing Heine \& Kuteva (2007), normally starts up as a violation of a historically determined grammar - thus in Haider's terms as ungrammatical - and is then propagated through the speakers' community and becomes acceptable. Adopting Haider's radically antithetic view, we are led to the paradoxical conclusion that language change should be considered illusory, because it produces ungrammatical but acceptable structures! 


\section{References}

Abraham, Werner. 2004. The grammaticalization of the infinitival preposition - Toward a theory of 'grammaticalizing reanalysis'. Journal of Comparative Germanic Linguistics 7. 111-170.

Ágel, Vilmos. 2001. Gegenwartsgrammatik und Sprachgeschichte: Methodologische Überlegungen am Beispiel der Serialisierung im Verbalkomplex. Zeitschrift für germanistische Linguistik 29. 319-331.

Askedal, John Ole. 1998. Zur Syntax infiniter Verbalformen in den Berthold von Regensburg zugeschriebenen Predigten. Vorstufe der topologischen Kohärenz-Inkohärenz-Opposition. In John Ole Askedal (ed.), Historische germanische und deutsche syntax, 231-259. Frankfurt/ Main: Lang.

Bader, Markus \& Tanja Schmid. 2009. Verb clusters in colloquial German. Journal of Comparative Germanic Linguistics 12. 175-228.

Bech, Gunnar. 1955/57. Studien über das deutsche verbum infinitum. Copenhagen: Munksgaard (Reprint Tübingen: Niemeyer, 1983).

Bech, Gunnar. 1963. Grammatische Gesetze im Widerspruch. Lingua 12. 291-299.

Betten, Anne. 1987. Grundzüge der Prosasyntax. Tübingen: Niemeyer.

Bybee, Joan. 2006. From usage to grammar: The mind's response to repetition. Language 82(4). $711-733$.

Croft, William. 2000. Explaining language change. London: Longman.

Demske, Ulrike. 2001. Zur Distribution von Infinitivkomplementen im Althochdeutschen. In Reimar Müller \& Marga Reis (eds.), Modalität und Modalverben im Deutschen, 61-86. Hamburg: Buske.

Ebert, Robert Peter. 1976. Infinitival complements constructions in early new high German. Tübingen: Niemeyer.

Ebert, Robert Peter. 1999. Historische Syntax des Deutschen II 1330-1750, 2nd edn. Berlin: Weidler.

Eisenberg, Peter, George Smith \& Oliver Teuber. 2001. Ersatzinfinitiv und Oberfeld: Ein großes Rätsel der deutschen Syntax. Deutsche Sprache 29(3). 242-260.

Eroms, Hans-Werner. 2006. Die Entwicklung des "Ersatzinfinitivs" im Deutschen. In Michail Kotin, Piotr Krycki, Marek Laskowski \& Tadeusz Zuchewicz (eds.), Das Deutsche als Forschungsobjekt und als Studienfach, 79-93. Frankfurt/Main: Lang.

Fischer, Olga. 1994. The fortunes of the Latin-type accusative and infinitive construction in Dutch and English compared. In Toril Swan, Endre Morck \& Olaf J. Westvik (eds.), Language change and language structure: Older Germanic languages in comparative perspective, 91-133. Berlin \& New York: Mouton de Gruyter.

Francis, Elaine J. \& Laura A. Michaelis. 2003. Mismatch: A crucible for linguistic theory. In Elaine J. Francis \& Laura A. Michaelis (eds.), Mismatch: Form-function incongruity and the architecture of grammar, 1-27. Stanford, CA: CSLI.

Gaeta, Livio. 1998. The inflection vs. derivation dichotomy: The case of German infinitives". In Bernard Caron (ed.), Proceedings of the XVI International Congress of Linguists (Paris, 20-25 July 1997). Oxford: Pergamon, Paper no. 0199.

Gaeta, Livio. 2008. Mismatch: Grammar distortion and grammaticalization. In María José López-Couso \& Elena Seoane (eds.), Rethinking grammaticalization: New perspectives, 103-127. Amsterdam: John Benjamins. 
Gaeta, Livio. 2010a. Analogical change. In Silvia Luraghi \& Vit Bubenik (eds.), A companion to historical linguistics, 147-160. London \& New York: Continuum.

Gaeta, Livio. 2010b. The invisible hand of grammaticalization: West-Germanic substitutive infinitive and the prefix ge-. In Wolfgang U. Dressler, Dieter Kastovsky, Hans Christian Luschützky \& Franz Rainer (eds.), Variation and change in morphology, 89-105. Amsterdam: John Benjamins.

Goldberg, Adele \& Ray Jackendoff. 2004. The English resultative as a family of constructions. Language 80. 532-568.

Grønvik, Ottar. 1986. Über den Ursprung und die Entwicklung der aktiven Perfekt- und Plusquamperfektkonstruktionen des Hochdeutschen. Oslo: Solum Forlag.

Haider, Hubert. 2003. V-clustering and clause union - causes and effects. In Pieter Seuren \& Gerard Kempen (eds.), Verb constructions in German and Dutch, 91-126. Amsterdam: John Benjamins.

Haider, Hubert. 2011. Grammatische Illusionen. Lokal wohlgeformt - global deviant. Zeitschrift für Sprachwissenschaft 30(2). 223-257.

Harris, Alice C. 2003. Cross-linguistic perspectives on syntactic change. In Brian D. Joseph \& Richard Janda (eds.), The handbook of historical linguistics, 529-551. Oxford: Blackwell.

Harris, Alice C. \& Lyle Campbell. 1995. Historical syntax in cross-linguistic perspective. Cambridge: Cambridge University Press.

Haspelmath, Martin. 1989. From purposive to infinitive - a universal path of grammaticization. Folia Linguistica Historica 10. 287-310.

Heine, Bernd \& Tania Kuteva. 2003. Contact-induced grammaticalization. Studies in Language 27(3). 529-572.

Heine, Bernd \& Tania Kuteva. 2007. The genesis of grammar. Oxford: Oxford University Press.

Himmelmann, Nikolaus P. 2004. Lexicalization and grammaticization. In Walter Bisang, Nikolaus P. Himmelmann \& Björn Wiemer (eds.), What makes grammaticalization? A look from its fringes and its components, 21-42. Berlin \& New York: Mouton de Gruyter.

Hock, Hans Heinrich. 1991. Principles of historical linguistics, 2nd edn. Berlin \& New York: Mouton de Gruyter.

Kotin, Michail L. 2000. Das Partizip II in hochdeutschen periphrastischen Verbalfügungen im 9.-15. Jh. Zur Ausbildung des analytischen Sprachbaus. Zeitschrift für germanistische Linguistik 28. 319-345.

Merkes, Peter Wilhelm. 1895. Der neuhochdeutsche Infinitiv als Teil einer umschriebenen Zeitform. Historisch-grammatische Betrachtungen. Göttingen: Universität Göttingen dissertation.

Paul, Hermann. [1920] 1995. Prinzipien der Sprachgeschichte, 10th edn. Tübingen: Niemeyer.

Reis, Marga. 1979. Ansätze zu einer realistischen Grammatik. In Klaus Grubmüller, Ernst Hellgardt, Heinrich Jellissen \& Marga Reis (eds.), Befund und Deutung: zum Verhältnis von Empirie und Interpretation in Sprach- und Literaturwissenschaft, 1-21. Tübingen: Niemeyer.

Schrodt, Richard. 2004. Althochdeutsche Grammatik II. Syntax. Tübingen: Niemeyer.

Schmid, Tanja. 2005. Infinitival Syntax: Infinitivus Pro Participio as a repair strategy. Amsterdam: John Benjamins.

Schmid, Tanja \& Ralf Vogel. 2004. Dialectal variation in German 3-verb clusters: A surfaceoriented optimality theoretic account. Journal of Comparative Germanic Linguistics 7. 235-274.

Speyer, Augustin. 2001. Ursprung und Ausbreitung der AcI-Konstruktion im Deutschen. Sprachwissenschaft 26. 145-187. 
Sternefeld, Wolfgang. 2006. Syntax. Eine morphologisch motivierte generative Beschreibung des Deutschen, Vol. 2. Tübingen: Stauffenburg.

Traugott, Elizabeth C. \& Richard B. Dasher. 2005. Regularity in semantic change. Cambridge: Cambridge University Press.

Vogel, Ralf. 2009. Skandal im Verbalkomplex: Betrachtungen zur scheinbar inkorrekten Morphologie in infiniten Verbkomplexen des Deutschen. Zeitschrift für Sprachwissenschaft 28. 307-346.

Zwart, Jan-Wouter. 2005. Continental West-Germanic languages. In Guglielmo Cinque \& Richard S. Kayne (eds.), The Oxford handbook of comparative syntax, 903-946. New York \& Oxford: Oxford University Press.

\section{Author's address}

StudiUm - Dipartimento di Studi Umanistici

Università di Torino

via S. Ottavio 20

I-10124 Torino, Italy

livio.gaeta@unito.it 